\title{
Chloroplast DNA Restriction Fragment Variation among Strawberry (Fragaria spp.) Taxa
}

\author{
Richard E. Harrison' and James J. Luby ${ }^{2}$ \\ Department of Horticultural Science, University of Minnesota, 1970 Folwell Avenue, St. Paul, MN 55108 \\ Glenn R. Furnier ${ }^{3}$ \\ Departments of Forest Resources and Plant Biology, University of Minnesota, 1530 Cleveland Avenue \\ North, St. Paul, MN 55108
}

ADDITIONAL INDEX WORDS. phylogenetics, RFLP, cpDNA, Fragaria $\times$ ananassa, germplasm

\begin{abstract}
Restriction fragment-length polymorphisms (RFLPs) of chloroplast DNA (cpDNA) were used to study phylogenetic relationships among twenty-six Fragaria taxa and two closely related species, Potentilla fruticosa L. and Duchesnea indica (Andrews) Focke. Sixteen restriction enzymes and probes of the entire Nicotiana tabacum L. chloroplast genome revealed a very low level of variation among the Fragaria taxa, limiting phylogenetic resolution. However, Fragaria appears to be more closely related to Potentilla than Duchesnea. The diploid taxa, $F$. iinumae Makino, $F$. nilgerrensis Schlect. and $F$. vesca $L$. were the most divergent Fragaria taxa and $F$. iinumae appears to be the most ancestral taxon. Little variation was revealed within the economically important octoploid group of taxa, which gave rise to the cultivated strawberry, and no progenitor taxa to the octoploid group could be identified. The lack of variation in the chloroplast genome suggests that these Fragaria species may be of relatively recent evolutionary origin.
\end{abstract}

Fragaria spp. (Rosaceae, Rosoideae, Potentilleae) are lowgrowing herbs endemic to various temperate environments in the northern and southern hemispheres. Morgan et al. (1994) studied sequence data of the chloroplast gene encoding the large subunit of ribulose-bisphosphate carboxylase $(r b c \mathrm{~L})$ to resolve many phylogenetic relationships between Fragaria and its closest relatives in Rosaceae, but phylogenetic relationships within the genus remain unclear. Current Fragaria taxonomy, based on cytology, interspe-

Table 1. Name, ploidy level and location of wild strawberry (Fragaria) species ${ }^{2}$.

\begin{tabular}{|c|c|c|}
\hline Species & Ploidy & Range \\
\hline F. vesca L. & $2 \mathrm{x}$ & North America, northern Asia, and Europe \\
\hline F. viridis Duch. & $2 \mathrm{x}$ & Europe and western Asia \\
\hline$F$. nilgerrensis Schlect. & $2 x$ & Southern and eastern Asia \\
\hline F. daltoniana J. Gay & $2 \mathrm{x}$ & Himalayas \\
\hline F. nubicola Lindl. & $2 \mathrm{x}$ & Himalayas \\
\hline F. iinumae Makino. & $2 \mathrm{x}$ & Japan \\
\hline F. yezoensis Hara. & $2 \mathrm{x}$ & Japan \\
\hline F. mandshurica Staudt & $2 \mathrm{x}$ & Northern Asia \\
\hline F. nipponica Lindl. & $2 \mathrm{x}$ & Japan \\
\hline F. corymbosa Losinsk & $4 \mathrm{x}$ & Northern China \\
\hline F. orientalis Losinsk & $4 \mathrm{x}$ & Northern Asia \\
\hline F. moupinensis French. & $4 \mathrm{x}$ & Southern China \\
\hline F. moschata Duch. & $6 \mathrm{x}$ & Northern and central Europe \\
\hline F. chiloensis (L.) Duch. & $8 \mathrm{x}$ & North and South America, Hawaii \\
\hline F. virginiana Duch. & $8 \mathrm{x}$ & North America \\
\hline F. iturupensis Staudt & $8 \mathrm{x}$ & Japan \\
\hline$F . \times$ ananassa Duch. & $8 \mathrm{x}$ & Cultivated form ${ }^{y}$ \\
\hline
\end{tabular}

${ }^{\mathrm{z}}$ Adapted from Hancock and Luby (1993).

${ }^{y}$ Interspecific complex of $F$. chiloensis and $F$. virginiana. Natural hybrids between $F$. chiloensis and $F$. virginiana are also endemic to parts of the Pacific Northwest (Staudt, 1962).

Received for publication 28 Feb. 1996. Accepted for publication 26 June 1996. This work was funded by the Minnesota Agricultural Experiment Station, St. Paul, scientific journal series paper no. 21,897. The cost of publishing this paper was defrayed in part by the payment of page charges. Under postal regulations, this paper therefore must be hereby marked advertisement solely to indicate this fact. 'Former graduate research assistant. Current address: The Scottish Crop Research Institute, Soft Fruit and Perennial Crops Dept., Mylnefield Research Services, Ltd., Invergowrie, Dundee DD2 5DA, Scotland.

${ }^{2}$ Professor; to whom reprint requests should be sent.

${ }^{3}$ Associate professor. cific fertility, and morphological information describes at least 16 Fragaria species with many subspecies (Table 1). Four basic fertility groups in the genus are associated primarily at the $2 \mathrm{x}, 4 \mathrm{x}$, 6x, and 8x ploidy levels (Table 1) (Hancock and Luby, 1993). Species are further differentiated by morphological characters such as, leaf, flower, fruit, and runner traits, but these data provide only limited insight into the phylogenetic relationships among Fragaria taxa.

Genetic relationships have been studied among some Fragaria species in the diploid $F$. vesca and octoploid $F$. chiloensis (L.) 
Duch. and $F$. virginian $a$., with studies of photosynthetic patterns (Cameron and Hartley, 1990; Chabot, 1978; Hancock et al., 1989; Jurik, 1979), mating systems, isozyme variation (Arulsekar and Bringhurst, 1981; Hancock and Bringhurst, 1978, 1979, 1980), and ecological and morphological variation (Angevine, 1983; Jensen and Hancock, 1981; Stahler, 1990). Few studies have included Eurasian taxa and none have placed this information into a phylogenetic context.

Many Fragaria species have desirable fruit, but only $F$. Xananassa Duch., an interspecific-hybrid complex between the two octoploid species, $F$. virginiana and $F$. chiloensis, is commercially cultivated to any great extent. Although this hybrid occurs naturally in some parts of the Pacific Northwest of the United States and British Columbia (Staudt, 1989), the cultivated strawberry is essentially derived from artificial hybridizations. Compared to many cultivated crops, this origin is relatively recent, dating to the 18 th century (Darrow, 1966), and years of selection for adaptation to cultivated environments has reduced genetic diversity within the cultivated strawberry (Dale and Sjulin, 1990; Luby et al., 1991; Sjulin and Dale, 1987). Because a narrow genetic base can be associated with inbreeding depression and vulnerability to diseases, pests, and environmental stresses (Luby and Stahler, 1993), breeders are interested in expanding the narrow genetic base of the strawberry by incorporating wild relatives into the breeding programs. Although many useful traits will come from the founding species, $F$. chiloensis and $F$. virginiana, beneficial genes may also come from closely related species. An understanding of the phylogenetic relationships among Fragaria species allows breeders to search the genus systematically based on genetic similarities to $F$. xananassa. These phylogenetic relationships may also reveal relationships with previously disregarded taxa that could lead to new sources of genes for genetic improvement.

Analysis of DNA restriction fragment-length polymorphisms (RFLPs) in the chloroplast (cpDNA) and nuclear genomes has provided information on phylogenetic relationships within many taxonomic groups, including Brassica (Palmer et al., 1983), Zea (Doebley et al., 1987), Pennisetum (Gepts and Clegg, 1989), Persea (Furnier et al., 1990), Glycine (Doyle et al., 1990), and Vitis (Bourquin et al., 1993). Analysis of cpDNA has been particularly informative because the genome is small, simplifying interpretation, and the rate of evolution is slow enough that simple variation can be detected among genera, species, and occasionally within species (Palmer 1986). Chloroplast DNA is also unaffected by changes in ploidy that can complicate phylogenetic analyses (Palmer 1986), a factor particularly important in Fragaria, with its array of ploidy levels. In most angiosperms, cpDNA is inherited maternally, although biparental (Smith et al., 1986) and paternal inheritance (Schumann and Hancock, 1989) have also been reported. We used cpDNA RFLPs to estimate phylogenetic relationships among a sample of Fragaria taxa.

Table 2. Geographic origins and taxa information of the accessions.

\begin{tabular}{|c|c|c|c|c|}
\hline \multicolumn{2}{|c|}{ Taxa } & \multirow{2}{*}{$\frac{\text { Ploidy }}{2 \mathrm{x}}$} & \multirow{2}{*}{$\begin{array}{l}\text { Origin } \\
\text { California }\end{array}$} & \multirow{2}{*}{$\begin{array}{l}\text { Source/accession no. } \\
\text { NCGR }^{2} / \text { FRA } 371\end{array}$} \\
\hline 1 & Fragaria vesca ssp. califormica & & & \\
\hline 2 & F. vesca ssp. americana & $2 x$ & Nebraska & Univ. of MN/N92143 \\
\hline 3 & F. vesca ssp. vesca & $2 \mathrm{x}$ & Finland & NCGR/FRA 438 \\
\hline 4 & F. vesca ssp. vesca & $2 \mathrm{x}$ & Sweden & NCGR/FRA $\ 10$ \\
\hline 5 & F. viridis & $2 \mathrm{x}$ & Germany & NCGR/FRA 333 \\
\hline 6 & F. viridis & $2 \mathrm{x}$ & Germany & NCGR/FRA 341 \\
\hline 7 & F. nilgerrensis & $2 \mathrm{x}$ & China & Berlin Bot. Garden/053-10-84-40 \\
\hline 8 & F. nilgerrensis & $2 \mathrm{x}$ & Yunnan Provice, China & Berkely Bot. Garden $/ 84.0771^{\mathrm{y}}$ \\
\hline 9 & F. iinumae & $2 \mathrm{x}$ & Japan & NCGR/FRA 377 \\
\hline 10 & $F$. iinumae & $2 \mathrm{x}$ & Japan & Univ. of California, Davis ${ }^{x}$ \\
\hline 11 & F. nubicola & $2 \mathrm{x}$ & Pakistan & NCGR/FRA 520 \\
\hline 12 & $F$. orientalis & $4 x$ & Asia & NCGR/FRA $536^{w}$ \\
\hline 13 & $F$. moschata & $6 x$ & Germany & NCGR/FRA 609 \\
\hline 14 & F. moschata & $6 x$ & Europe & NCGR / FRA 157 \\
\hline 15 & F. virginiana spp. virginiana & $8 x$ & Minnesota & Univ. of MN/N92145 \\
\hline 16 & $F$. virginiana spp. virginiana & $8 \mathrm{x}$ & Michigan & Univ. of MN/N92144 \\
\hline 17 & F. virginiana spp. virginiana & $8 x$ & New Hampshire & NCGR/FRA 381 \\
\hline 18 & $F$. virginiana ssp. virginiana & $8 \mathrm{x}$ & Maryland & NCGR/FRA 67 \\
\hline 19 & $F$. virginiana ssp. platypetala & $8 \mathrm{x}$ & Nevada & NCGR/FRA 370 \\
\hline 20 & F. virginiana ssp. platypetala & $8 \mathrm{x}$ & Oregon & NCGR/FRA 99 \\
\hline 21 & $F$. virginiana ssp. glauca & $8 \mathrm{x}$ & Wyoming & NCGR/FRA 104 \\
\hline 22 & $F$. chiloensis ssp. pacifica & $8 x$ & Alaska & NCGR/FRA 606 \\
\hline 23 & F. chiloensis ssp. lucida & $8 \mathrm{x}$ & California & NCGR/FRA 366 \\
\hline 24 & F. chiloensis ssp. chiloensis & $8 x$ & Chile & NCGR/FRA 393 \\
\hline 25 & F. chiloensis ssp. chiloensis & $8 \mathrm{x}$ & Peru & NCGR/FRA 372 \\
\hline 26 & F. chiloensis ssp. chiloensis & $8 x$ & Colombia & NCGR/FRA 24 \\
\hline 27 & Potentilla fruticosa 'Jackmans' & $2 \mathrm{x}$ & Cultivar & Willowood Gardens; Bowler, Wis. \\
\hline 28 & Duchesnea indica & $12 \mathrm{x}$ & Southern and eastern Asia & North. Hort. Soc. $/ 490^{v}$ \\
\hline
\end{tabular}

${ }^{\mathrm{z}}$ National Clonal Germplasm Repository, Corvallis Ore.

${ }^{y}$ Originally classified as $F$. moupinensis by BBG; Reclassified by NCGR and G. Staudt (K. Hummer, curator at NCGR, personal communication). ${ }^{x}$ Received from R.S. Bringhurst, specific origins unknown.

"Now classified as "F. hybrid" by NCGR due to questionable pedigree (K. Hummer, curator at NCGR, personal communication; also see text).

${ }^{v}$ Seed lot from the Northern Horticultural Society; Harrogate, England; 1991 catalog no. 490. 
Table 3. Probes derived from the SolClone Top40 clone bank ${ }^{2}$ of Nicotiana tabacum cpDNA.

\begin{tabular}{lccl}
\hline \hline Probe & Size $(\mathrm{kb})$ & Coordinates $^{\mathrm{y}}$ & Subclones $^{\mathrm{x}}$ \\
\hline SC1-8 & 23.4 & $153746-21947$ & $1-8$ \\
SC9a-15 & 21.5 & $21947-47699$ & $9 \mathrm{a}, 9 \mathrm{~b}, 10-15$ \\
SC16-24 & 26.4 & $47699-74167$ & $16-19,20 \mathrm{a}, 20 \mathrm{~b}, 21-24$ \\
SC25-33 & 27.0 & $74167-104801$ & $25-28,29 \mathrm{a}, 29 \mathrm{~b}, 30,33$ \\
SC34-40 & 25.8 & $104801-130600$ & $34-40$ \\
\hline
\end{tabular}

${ }^{2}$ Olmstead and Palmer (1992).

yCoordinates for the Nicotiana tabacum cpDNA sequence (Shinozaki et al., 1986).

'Original subclone reference numbers for SolClone Top 40.

\section{Materials and Methods}

We assayed 26 Fragaria accessions representing 16 different taxa from 9 species (Table 2). Potentilla fruticosa and Duchesnea indica are closely related to Fragaria, and these accessions were included as comparative outgroup species (Darrow, 1966; Morgan et al., 1994). Plants were rooted in $15-\mathrm{cm}$ pots in a 2 peat : 1 sand $: 1$ perlite (by volume) medium from runners or divisions of the original plant during Summer 1992. They were first grown under greenhouse conditions and then moved to a cold frame in July. In early November the plants were moved to $4^{\circ} \mathrm{C}$ cooler for 8 weeks and in early January 1993 they were returned to the greenhouse.

In February, about $1 \mathrm{~g}$ of newly expanded or expanding leaf tissue was collected from each accession and used to isolate total cellular DNA (Doyle and Doyle, 1990). DNA yields using this method averaged $0.1 \mathrm{mg} \mathrm{DNA} / \mathrm{g}$ of fresh tissue. One microgram of DNA per sample was digested separately with 10 units of the restriction enzymes, BamHI, BglI, BgIII, BstXI, CfoI, ClaI, DraI, EcoRI, EcoRV, HindIII, HpaII, KpnI, MspI, SalI, SstI, and XbaI. DNA fragments were separated by electrophoresis on $0.8 \%$ agarose gels in $1 \times$ TBE buffer $(0.09 \mathrm{M}$ tris-borate and $0.002 \mathrm{M}$ EDTA; Sambrook et al., 1989). DNA was transferred to nylon membranes (Magnagraph; Micron Separations, Inc., Westboro, Mass.) using $20 \times \mathrm{SSC}$ ( $3 \mathrm{~m} \mathrm{NaCl}$ and 0.3 м sodium citrate; Sambrook et al., 1989) as a transfer buffer. DNA fragments were hybridized with ${ }^{32} \mathrm{P}$-labelled (Feinberg and Vogelstein, 1984) or digoxigeninlabelled (Boehringer Mannheim Corp.; Indianapolis) Nicotiana tabacum chloroplast DNA (cpDNA) fragments (Olmstead and Palmer, 1992). Adjacent fragments were combined into five composite probes ranging in size from 23.4 to $27.0 \mathrm{~kb}$, which together covered the entire chloroplast genome of $N$. tabacum (Table 3 ). Hybridizations and washes of the membranes followed the methods of Palmer (1986), and fragments were visualized by autoradiography or chemiluminescence. Hybridized probe was removed before rehybridization in washes of $0.4 \mathrm{M} \mathrm{NaOH}$ at $42{ }^{\circ} \mathrm{C}$ for 30 min, followed by $30 \mathrm{~min}$ at $42^{\circ} \mathrm{C}$ in $0.1 \times \mathrm{SSC}, 0.5 \% \mathrm{SDS}$ (sodium dodecyl sulfate), and $0.2 \mathrm{M}$ tris- $\mathrm{HCl}(\mathrm{pH} 7.5)$.

When we could determine that a polymorphism was due to a particular restriction site mutation, we used it as a single character in the analysis. However, many polymorphisms could not be explained as simple restriction site changes. These polymorphisms may be due to more complex structural rearrangement differences between the taxa. As a conservative approach, if a set of polymorphic fragments was common among a group of taxa, these were interpreted as a single character (e.g., mutation 5, Table 4). However, each combination of restriction enzyme and probe was scored independently, meaning that some mutations could have been be scored more than once. We estimated phylogenetic relationships by parsimony analysis, using the bootstrap method with heuristic search in PAUP 3.0q (Swofford, 1990). A bootstrap 70\% majority-rule consensus tree was developed using 100 replications.

\section{Results and Discussion}

Of 127 mutations observed, 61 involved only the outgroup species $P$. fruticosa and $D$. indica, leaving 66 phylogenetically informative mutations for analysis (Table 4). Fifteen of the observed mutations could be classified as restriction site changes (e.g., mutation 1, Table 4). Structural rearrangements between the chloroplast genomes of Nicotiana and Fragaria and Potentilla and Duchesnea have apparently been sufficiently numerous and complex to prevent us from discerning the nature of the remaining mutations (Table 4).

Variation within Fragaria proved to be low, limiting the resolution of the phylogenetic analysis. Several relationships, however, were resolved (Fig. 1). Fragaria and Potentilla appeared to be more closely related than Fragaria and Duchesnea, sharing six characters (mutations $4,9,13,14,21$, and 35 , Table 4) vs. only one (mutation 10, Table 4). This relationship is supported by fertility data, in which hybrid seedlings have been obtained from $F$. ×ananassa $\times P$. fruticosa crosses, but not from $D$. indica $\times F$. Xananassa (Rose et al., 1993).

The diploid taxa, $F$. iinumae, $F$. nilgerrensis, and the $F$. vesca ssp. vesca, were the most divergent of the Fragaria taxa (Table 4, Fig. 1). Fragaria iinumae was separated from the other taxa by 21 characters (Fig. 1) and shared more characters with Potentilla than any other Fragaria taxon (mutations 4, 13, 21, 35, Table 4), suggesting that it is the most ancestral of the Fragaria taxa studied. It is also morphologically distinct, being the only deciduous species in the genus and the only diploid species with glaucous leaves (Luby et al., 1991; Staudt 1989).

Similarly, $F$. nilgerrensis is divergent, separated from the other Fragaria taxa by 11 characters (Table 4, Fig. 1). It is also genetically quite distinct, based on interspecific sterility (Dowrick and Williams, 1959) and morphological characteristics (Staudt, 1989). Eight characters separate the European $F$. vesca ssp. vesca from all other taxa, suggesting that this taxon is relatively divergent from most other Fragaria taxa, but partial fertility has been reported among $F$. vesca, $F$. viridis Duch., $F$. nubicola Lindl., and F. nilgerrensis (Dowrick and Williams, 1959; Hancock et al., 1991).

Characters shared by $F$. orientalis Losinsk $(2 \mathrm{n}=4 \mathrm{x}=28)$ and $F$. moschata Duch. $(2 \mathrm{n}=6 \mathrm{x}=42)$ suggest that these species may represent a polyploid series (Fig. 1). However, visual inspection of the $F$. orientalis accession (USDA accession FRA 536) suggests that there is some question concerning the assignment of this particular accession to $F$. orientalis (Table 2). This accession presumably derives from open pollination and may not accurately represent pure F. orientalis, so the USDA National Clonal Germplasm Repository is now classifying it as "F. hybrid". If the maternal plant was correctly labelled and the cpDNA was inherited maternally, then our data should accurately represent the cpDNA of $F$. orientalis. Chromosome counts of this accession were 28, as 


\begin{tabular}{|c|c|c|c|c|c|}
\hline \multirow[b]{2}{*}{ Mutation $^{2}$} & \multirow[b]{2}{*}{ Enzyme } & \multirow[b]{2}{*}{ Probe } & \multicolumn{2}{|c|}{ Polymorphic fragments } & \multirow[b]{2}{*}{$\operatorname{Taxa}^{y}$} \\
\hline & & & Present $(\mathrm{Kb})$ & Absent $(\mathbf{K b})$ & \\
\hline 1 & BamHI & SC1-8 & $1.2+0.8$ & 2.0 & 5,6 \\
\hline 2 & BamHI & SC1-8 & 12.8 & & $15-26$ \\
\hline 3 & CfoI & SCI-8 & 4.3 & 1.85 & 7,8 \\
\hline 4 & CfoI & $\mathrm{SCl}-8$ & 1.6 & 1.85 & $9,10,27$ \\
\hline 5 & $C f o \mathrm{I}$ & SC1-8 & $9.0,1.6$ & $2.9,1.6$ & 9,10 \\
\hline 6 & $C f \circ \mathrm{I}$ & $\mathrm{SC} 1-8$ & & 2.0 & 9,10 \\
\hline 7 & ClaI & SC1-8 & 4.8 & & $15-26$ \\
\hline 8 & Dral & $\mathrm{SC} 1-8$ & 0.7 & & 7,8 \\
\hline 9 & EcoRI & SC1-8 & 9.1 & 4.2 & $7,8,27$ \\
\hline 10 & $E c o$ RI & $\mathrm{SC} 1-8$ & 3.6 & 2.9 & $9,10,28$ \\
\hline 11 & EcoRI & SC1-8 & 3.0 & & 9,10 \\
\hline 12 & Hindlll & SC1-8 & 1.9 & & $15-26$ \\
\hline 13 & Hind $\amalg$ & SC1-8 & 2.8 & & $9,10,27$ \\
\hline 14 & $M s p \mathrm{I}$ & $\mathrm{SC} 1-8$ & 4.4 & 6.2 & $7,8,27$ \\
\hline 15 & SalI & SC1-8 & 11.4 & & 9,10 \\
\hline 16 & $X b a I$ & $\mathrm{SCl}-8$ & $2.3+2.1$ & 4.4 & 9,10 \\
\hline 17 & $X b a I$ & SC1-8 & 3.7 & $2.7+1.0$ & 3 \\
\hline 18 & $X b a \mathrm{I}$ & $\mathrm{SC} 1-8$ & 2.4 & $1.3+1.1$ & 7,8 \\
\hline 19 & $X b a \mathrm{I}$ & $\mathrm{SCl}-8$ & 3.2 & & 9,10 \\
\hline 20 & $X b a I$ & SCl-8 & 2.0 & & $15-26$ \\
\hline 21 & BamHI & SC9a-15 & $7.7+1.2$ & 9.9 & $9,10,27$ \\
\hline 22 & $B g I I I$ & SC9a-15 & 0.9 & & 7,8 \\
\hline 23 & CfoI & SC9a-15 & 3.3 & $1.8+1.5$ & 7,8 \\
\hline 24 & $C l a \mathrm{I}$ & SC9a-15 & 6.4 & 7.2 & 9,10 \\
\hline 25 & DraI & SC9a-15 & 8.9 & $5.6+3.3$ & 9,10 \\
\hline 26 & DraI & SC9a-15 & 3.9 & 4.1 & $5-8$ \\
\hline 27 & DraI & SC9a-15 & 1.0 & 2.6 & 3,4 \\
\hline 28 & $E c o$ RI & SC9a-15 & $1.4+0.5$ & 1.9 & $7-8$ \\
\hline 29 & EcoRV & SC9a-15 & $4.3,3.1$ & 5.9 & 3,4 \\
\hline 30 & EcoRV & SC9a-15 & 2.4 & & $9,10,15-26$ \\
\hline 31 & HindIII & SC9a-15 & $1.9+0.9$ & 2.8 & 9,10 \\
\hline 32 & Hpall & SC9a-15 & 3.3 & $1.7+1.6$ & 7,8 \\
\hline 33 & KpnI & SC9a-15 & 4.7 & 5.3 & 9,10 \\
\hline 34 & SalI & SC9a-15 & 9.7 & & 9,10 \\
\hline 35 & BamHI & SC16-24 & $5.9+1.0$ & 6.9 & $9,10,27$ \\
\hline 36 & BstXI & SC16-24 & $10.6,8.8$ & & $5-10$ \\
\hline 37 & $C f o \mathrm{I}$ & SC16-24 & 4.0 & 3.7 & $5,6,9,10,15-26$ \\
\hline 38 & ClaI & $\mathrm{SCl} 16-24$ & 4.0 & 4.7 & 3,4 \\
\hline 39 & ClaI & SC16-24 & 4.5 & 4.7 & 7,8 \\
\hline 40 & DraI & $\mathrm{SCl6-24}$ & $4.3+0.3$ & 4.6 & 9,10 \\
\hline 41 & DraI & SC16-24 & 2.6 & 3.0 & $12-14$ \\
\hline 42 & DraI & $\mathrm{SCl} 6-24$ & 1.3 & & 9,10 \\
\hline 43 & Dral & SC16-24 & & 1.5 & $1-4,9,10$ \\
\hline 44 & EcoRI & SC16-24 & $1.4+0.5$ & 1.9 & 7,8 \\
\hline 45 & HindIII & SC16-24 & 0.9 & 2.9 & 9,10 \\
\hline 46 & DraI & SC $25-33$ & $1.3+1.1$ & 1.4 & 13,14 \\
\hline 47 & Dral & SC25-33 & 4.1 & 4.7 & 9,10 \\
\hline 48 & $E c o R I$ & SC25-33 & 11.6 & & 9,10 \\
\hline 49 & EcoRI & SC25-33 & 1.1 & & 7,8 \\
\hline 50 & HindIII & $\mathrm{SC} 25-33$ & 6.0 & & 9,10 \\
\hline 51 & KpnI & $\mathrm{SC} 25-33$ & $8.4,10.0$ & & 9,10 \\
\hline 52 & $B g l I$ & SC34-40 & 2.8 & & 3,4 \\
\hline 53 & BglII & SC34-40 & 6.9 & & 9,10 \\
\hline 54 & $B s t \mathrm{XI}$ & SC34-40 & 9.4 & & 3,4 \\
\hline 55 & $B s t \mathrm{XI}$ & SC34-40 & 12.3 & & 9,10 \\
\hline 56 & $B s t \times 1$ & SC34-40 & 12.3 & $13.3,20.0$ & $12-14$ \\
\hline 57 & KpnI & SC34-40 & 7.2 & & 3,4 \\
\hline 58 & $\kappa p n \mathbf{I}$ & SC34-40 & 7.4 & & 7,8 \\
\hline 59 & EcoRI & $\mathrm{SC} 34-40$ & 3.7 & $3.0+0.7$ & $12-14$ \\
\hline 60 & EcoRI & SC34-40 & 5.4 & & $1,3,4$ \\
\hline 61 & $E c o R V$ & SC34-40 & 7.5 & & 4 \\
\hline 62 & $K p n \mathrm{I}$ & SC34-40 & $1.6,1.2$ & & 3,4 \\
\hline 63 & $K p n \mathrm{I}$ & SC34-40 & 8.4 & & 9,10 \\
\hline 64 & SstI & SC34-40 & 5.6 & & 3,4 \\
\hline 65 & SstI & $\mathrm{SC} 34-40$ & 4.2 & & 18,19 \\
\hline 66 & $X b a I$ & SC34-40 & 8.2 & & 3 \\
\hline
\end{tabular}

${ }^{\mathrm{z}}$ All mutations within the large single copy region of the chloroplast genome. ${ }^{y}$ Numbers of taxa are as given in Table 2. 
expected for $F$. orientalis (Staudt, 1989), but data from an accurately classified accession of $F$. orientalis are necessary to clarify this situation.

Although the octoploid taxa have considerable geographical, morphological, and allozyme variation (Hancock and Bringhurst, 1981), they display strikingly little cpDNA variability, with all taxa grouped together by six mutations (mutations $2,7,12,20,29$, 37, Table 4). No species were clearly identified as ancestral to the octoploid taxa even though $F$. vesca has been implicated using cytogenetic information (Bringhurst and Khan, 1963; Senanayake and Bringhurst, 1967). Interspecific fertility among octoploids is high (Hancock et al., 1991), also suggesting that these species are closely related and may share a common ancestral maternal origin.

The value of cpDNA polymorphisms in establishing phylogenetic relationships is well documented (Palmer, 1987); however,

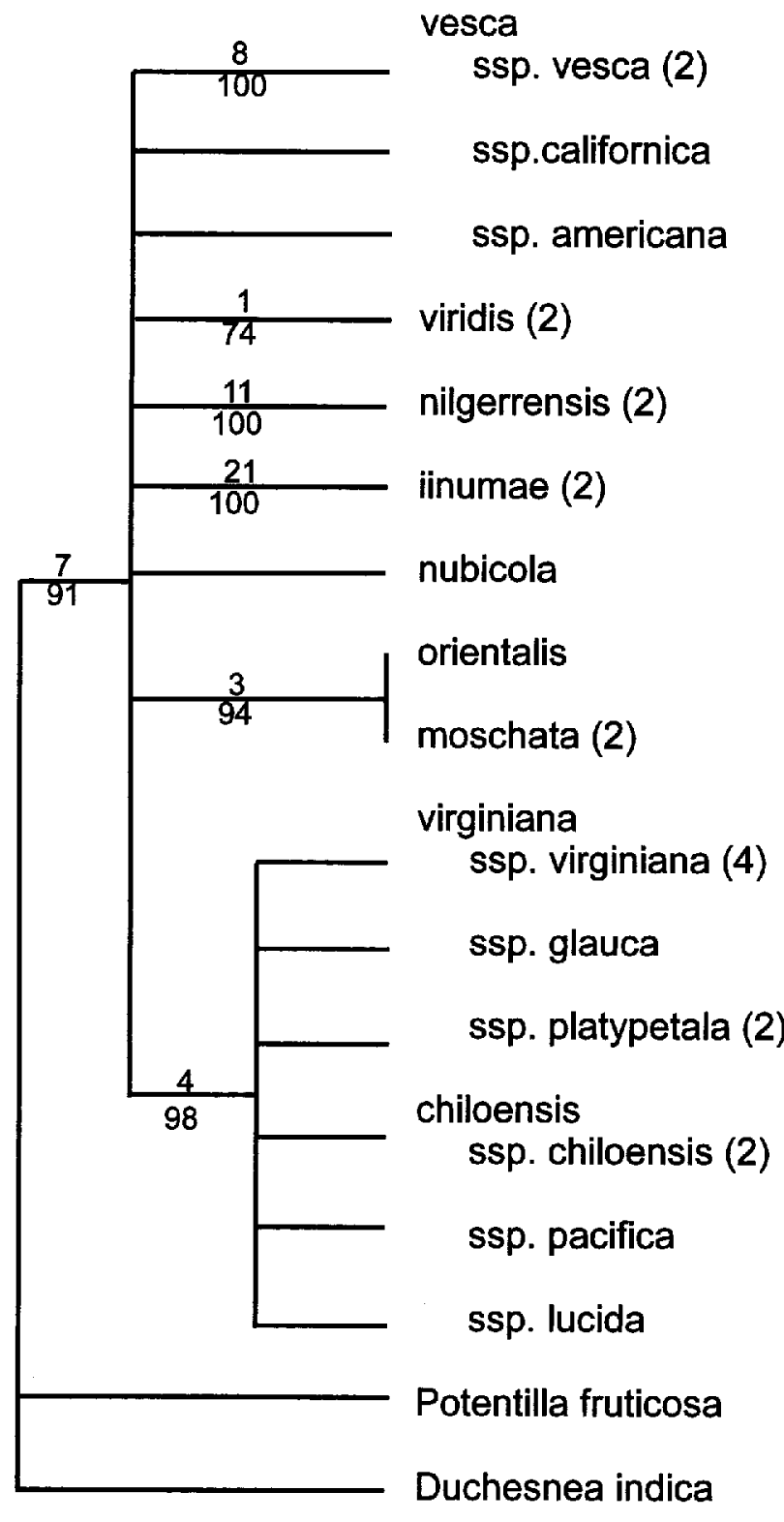

$4 x$

$6 x$

$8 x$

Fig. 1. Cladogram of the bootstrap $70 \%$ majority-rule consensus tree using 100 replications. The number of mutations that define each branch is shown above the branch lines and the number of times that each branch occurred out of 100 bootstrap replications is shown below the branch lines. Ploidy levels are shown at the right and the number of accessions representing a given taxa, if $>1$, are in parentheses.

sequence variability can be low in some cases, limiting phylogenetic resolution (Olmstead et al., 1990; Rieseberg et al., 1991). Schilling and Jansen (1989) observed no variation among a group of geographically and morphologically diverse Viguiera taxa and concluded that these species were of recent divergence from the other closely related genera in the study. In general, the Fragaria taxa studied had lower levels of mutation as ploidy levels increased, and this may suggest that the higher ploidy levels, includ ing the economically important octoploid taxa, are of relatively recent origin as compared with the diploid taxa.

The lack of variation among the octoploid taxa may suggest that these taxa are derived from a common ancestor. The precise origin of the octoploids remains unknown; however, the range of $F$. chiloensis extends west along the Aleutian Islands and another octoploid species, F. iturupensis Staudt, occurs in the Kuril Islands (Staudt, 1973), suggesting that polyploidization could have occurred in eastern Asia with the octoploid taxa then spread across the Bering Strait land bridge into North America.

The highest levels of polymorphism were among Fragaria, Potentilla, and Duchesnea, suggesting that cpDNA RFLP analysis is better suited for assessing variation at the subfamily (Rosoideae) and tribe (Potentilleae) levels and could potentially resolve some of the remaining questions concerning the ancestry of many of the economically valuable genera within the Rosaceae family.

Future phylogenetic studies of Fragaria will likely include Mendelian markers to reveal more variability among the taxa and, in conjunction with these cpDNA data, can reveal cases of interspecific hybridization (Furnier et al., 1990). This molecular information with the vast amounts of morphological and cytological data previously compiled (Darrow, 1966; Staudt, 1962, 1989) will allow breeders to incorporate nondomesticated germplasm more effectively in breeding programs.

\section{Literature Cited}

Angevine, M.W. 1983. Variations in demography of natural populations of the wild strawberries Fragaria vesca and $F$. virginiana. J. Ecol. 71:959-974.

Arulsekar, S. and R.S. Bringhurst. 1981. Genetic model for the enzyme marker PGI, its variability and use in elucidating the mating system in diploid California Fragaria vesca L. J. Hered. 72:117-120.

Bringhurst, R.S. and D.A. Khan. 1963. Natural pentaploid Fragaria chiloensis-F. vesca hybrids in coastal California and their significance in polyploid Fragaria evolution. Amer. J. Bot. 50:658-661.

Bourquin, J.-C., A. Sonko, L. Otten, and B. Walter. 1993. Restriction fragment length polymorphism and molecular taxonomy in Vitis vinifera L. Theor. Applied Genet. 87:431-438.

Cameron, J.S. and C.A. Hartley. 1990. Gas exchange characteristics of Fragaria chiloensis genotypes. HortScience 25:327-9.

Chabot, B.F. 1978. Environmental influences on photosynthesis and growth in Fragaria vesca. New Phytol. 80:87-98.

Dale, A. and T.M. Sjulin. 1990. Few cytoplasms contribute to North American strawberry cultivars. HortScience 25:1341-1342.

Darrow, G.M. 1966. The strawberry: History, breeding and physiology. Ist ed. Holt, Rinehart and Winston, New York.

Doebley, J., W. Renfroe, and A. Blanton. 1987. Restriction site variation in the Zea chloroplast genome. Genetics 117:139-147.

Dowrick, G.J. and H. Williams. 1959. Species crosses in the genus Fragaria. John Innes Hort. Inst. Annu. Rpt. 50:9-10.

Doyle, J.J. and J.L. Doyle. 1990. Isolation of plant DNA from fresh tissue. Focus 12:13-15.

Doyle, J.J., J.L. Doyle, A.D.H. Brown, and J.P. Grace. 1990. Multiple origins of polyploids in the Glycine tabacina complex inferred from chloroplast DNA polymorphism. Proc. Natl. Acad. Sci. USA 87:714717.

Feinberg, A.P. and B. Vogelstein. 1984. A technique for radiolabeling 
DNA restriction endonuclease fragments to high specific activity. Ann. Biochem. 137:266-267.

Furnier, G.R., M.P. Cummings, and M.T. Clegg. 1990. Evolution of the avocados as revealed by DNA restriction fragment variation. J. Hered. 81:183-188.

Gepts, P. and M.T. Clegg. 1989. Genetic diversity in pearl millet (Pennisetum glaucum [L.] R. Br.) at the DNA sequence level. J. Hered. 80:203-208.

Hancock, J.F. and R.S. Bringhurst. 1978. Inter-populational differentiation and adaptation in the perennial, diploid species Fragaria vesca $\mathrm{L}$. Amer. J. Bot. 65:795-803.

Hancock, J.F. and R.S. Bringhurst. 1979. Ecological differentiation in perennial, octoploid species of Fragaria. Amer. J. Bot. 66:367-375.

Hancock, J.F. and R.S. Bringhurst. 1980. Sexual dimorphism in the strawberry Fragaria chiloensis. Evolution 34:762-768.

Hancock, J.F. and R.S. Bringhurst. 1981. Evolution in California populations of diploid and octoploid Fragaria (Rosaceae): A comparison. Amer. J. Bot. 68:1-5.

Hancock, J.F. and J.J. Luby. 1993. Genetic resources at our doorstep: The wild strawberries. Bioscience 43:141-147.

Hancock, J.F., J.A. Flore, and G.J. Galletta. 1989. Variation in leaf photosynthesis rates and yield in strawberries. J. Hort. Sci. 64:449-454.

Hancock, J.F., J.L. Maas, C.H. Shanks, P.J. Breen, and J.J. Luby. 1991. Strawberries (Fragaria spp.), p. 489-546. In: J.N. Moore and J.R. Ballington (eds.). Genetic resources in temperate fruit and nut crops. Acta Hort., Wageningen, The Netherlands.

Jensen, R.J. and J.F. Hancock. 1981. Multivariate relationships among California strawberries. Bul. Torrey Bot. Club. 109:136-147.

Jurik, T.W., J.F. Chabot, and B.F. Chabot. 1979. Ontogeny of photosynthetic performance in Fragaria virginiana under changing light regimes. Plant Physiol. 63:542-547.

Luby, J.J., J.F. Hancock, and J.S. Cameron. 1991. Expansion of the strawberry germplasm base in North America, p. 65-75. In: A. Dale and J.J. Luby (eds.). The strawberry into the 21 st century. Timber Press, Portland Ore.

Luby, J.J. and M.M. Stahler. 1993. Collection and evaluation of Fragaria virginiana in North America. Acta Hort. 345:49-53.

Morgan, D.R., D.E. Soltis, and K.R. Robertson. 1994. Systematic and evolutionary implications of $r b c \mathrm{~L}$ sequence variation in Rosaceae. Amer. J. Bot. 81:890-903.

Olmstead, R.G., R.K. Jansen, H.J. Michaels, S.R. Downie, and J.D. Palmer. 1990. Chloroplast DNA and phylogenetic studies in Asteridae, p. 110-134. In: S. Kawano (ed.). Biological approaches and evolutionary trends in plants. Academic Press, London.

Olmstead, R.G. and J.D. Palmer. 1992. A chloroplast DNA phylogeny of the Solanaceae: Subfamilial relationships and character evolution. Ann. Missouri Bot. Gard. 79:346-360.

Palmer, J.D. 1986. Chloroplast DNA and phylogenetic relationships, p.
63-80. In: S.K. Dutta (ed.). DNA systematics. vol. 2. CRC Press, Boca Raton, Fla.

Palmer, J.D. 1987. Chloroplast DNA evolution and biosystematic uses of chloroplast DNA variation. Amer. Nat. 130:S6-S29.

Palmer, J.D., C.R. Shields, D.B. Cohen, and T.J. Orton. 1983. Chloroplast DNA evolution and the origin of amphidiploid Brassica species. Theor. Applied Genet. 65:181-189.

Rieseberg, L.H., S.M. Beckstom-Sternberg, A. Liston, and D.M. Arias. 1991. Phylogenetic and systematic inferences from chloroplast DNA and isozyme variation in Helianthus sect. Helianthus (Asteraceae). Syst. Bot. 16:50-76.

Rose, J.B., R.P. Jones, and D.W. Simpson. 1993. Anther culture and intergeneric hybridization of Fragaria Xananassa. Adv. Strawberry Res. 12:59-64.

Sambrook, J., E.F. Fritsch, and T. Maniatis. 1989. Molecular cloning: a laboratory manual. 2nd ed. Cold Spring Harbor Laboratory Press, Cold Spring Harbor, N.Y.

Schilling, E.E. and R.K. Jansen. 1989. Restriction fragment analysis of chloroplast DNA and the systematics of Viguiera and related genera (Asteraceae: Heliantheae). Amer. J. Bot. 76:1769-1778.

Schumann, C.F. and J.F. Hancock. 1989. Paternal inheritance of plastids in Medicago sativa. Theor. Appl. Genet. 78:863-866.

Senanayake, Y.D.A. and R.S. Bringhurst. 1967. Origin of Fragaria polyploids. I. cytological analysis. Amer. J. Bot. 54: 221-228.

Shinozaki, K., M. Ohme, M. Tanaka, T. Wakasungi, N. Hayashida, T. Matsubaysahi, N. Zaita, J. Chunwongse, J. Obokata, K. YamaguchiShinozaki, C. Ohto, K. Torazawa, B.Y. Meng, M. Sugita, H. Deno, T. Kamogashira, K. Yamada, J. Kusuda, F. Takaiwa, A. Kata, N. Tohidoh, H. Shimada, and M. Sugiura. 1986. The complete nucleotide sequence of tobacco chloroplast genome: Its gene organization and expression. Europ. Mol. Biol. Organ. J. 5:2043-2049.

Sjulin, T.M. and A. Dale. 1987. Genetic diversity of North American strawberry cultivars. J. Amer. Soc. Hort. Sci. 112:375-385.

Smith, S.E., E.T. Bingham, and R.W. Fulton. 1986. Transmission of chlorophyll deficiencies in Medicago sativa. Evidence for biparental inheritance of plastids. J. Hered. 77:35-38.

Stahler, M.M. 1990. Evaluation of variation in Minnesota/Wisconsin Fragaria virginiana for horticultural and morphological traits. $\mathrm{PhD}$ diss., Univ. of Minnesota, St. Paul.

Staudt, G. 1962. Taxonomic studies of the genus Fragaria. Typification of species known at the time of Linnaeus. Can. J. Bot. 40:869-886.

Staudt, G. 1973. Fragaria iturupensis, eine neue Erdbeerart aus Ostasien. Willdenowia 7:101-104.

Staudt, G. 1989. The species of Fragaria, their taxonomy and geographical distribution. Acta Hort. 265:23-33.

Swofford, D.L. 1990. PAUP: Phylogenetic analysis using parsimony version 3.0. Illinois Natural History Survey, Univ. of Illinois, Champaign. 